\title{
Sultestreikende asylsøker - hvor langt går pasientens rett til å nekte behandling?
}

\author{
Helsepersonelloven gir helsepersonell rett og plikt til å yte helsehjelp i tilfeller der hjelp er påtrengende nød- \\ vendig, selv om pasienten motsetter seg dette. Hjelpeplikten er imidlertid begrenset av tre særskilte unntak \\ i pasient- og brukerrettighetsloven, blant annet sultestreik. I denne artikkelen drøfter vi juridiske og etiske \\ aspekter ved et tilfelle der en pasient nektet behandling under henvisning til sultestreik.
}

\author{
Jørgen Dahlberg \\ jorged@medisin.uio.no \\ Vegard Dahl \\ > Se lederartikkel på side 9
}

En asylsøker i 50-årene ble brakt inn fra asylmottak til akuttmottaket med redusert bevissthet. Pasienten hadde sultestreiket i nesten sju uker. Han hadde i løpet av streikeperioden blitt slapp og kakektisk og ble lagt inn akutt på somatisk sykehus for behandling. Blodsukker dagen før innleggelse var målt til 2,4 mmol/1, ved innkomst $1,7 \mathrm{mmol} / \mathrm{l}$.

Anestesilege ble tilkalt til akuttavdelingen av medisinsk ansvarlig lege for å legge inn perifert venekateter (veneflon) med sikte på å få gitt intravenøs væske og ernæring.

I mottaket fremsto pasienten som redusert, men fortsatt våken. Anestesilegen tolket tilkallingen primært som anmodning om bistand for å få lagt venekateter for å stabilisere pasientens blodsukker. Idet anestesilegen startet prosedyren med kateterinnleggelse, trakk pasienten til seg armen $i$ en vegrende bevegelse og ytret ordet «sultestreiker» klart og tydelig.

Det ble da reist spørsmål ved om det var riktig å gå videre, eller om man skulle akseptere pasientens klare ytring. I den anledning ble det problematisert hvorvidt pasienten var samtykkekompetent i øyeblikket og om man således kunne legge vekt på hvordan pasienten uttrykte seg. Det ble videre reist spørsmål ved om man eventuelt skulle vente til pasienten mistet bevissthet for deretter å legge venekateter og iverksette livreddende behandling og på den måten unngå unødig tvang.

Psykiater ble konsultert for å avklare om pasienten kunne være påvirket av en psykiatrisk sykdom og for å få vurdert om pasienten fortsatt var samtykkekompetent.
Det ble konkludert med at pasienten ikke fremsto som påvirket av psykisk sykdom samt at pasienten fortsatt var samtykkekompetent. Det ble videre avklart at pasienten var innforstått med konsekvensene av å nekte hjelp, nemlig at det med rimelig sikkerhet ville ende med døden dersom det ikke ble gitt behandling eller pasienten selv umiddelbart begynte å ta til seg næring igjen. Det ble gjort klart at pasienten sulte-

\section{«Saken reiser både juridiske og etiske problemstillinger»}

streiket som en protest mot regelverket for utlendinger og at protesten var iverksatt for å få fokus på egen situasjon.

Saken reiser både juridiske og etiske problemstillinger.

\section{Juridiske problemstillinger}

De juridiske problemstillingene kan deles i to hovedspørsmål. Det første spørsmålet er om pasienten har truffet en informert og kompetent beslutning. Det andre spørsmålet er om helsepersonellet uansett er forpliktet til å behandle pasienten.

Det første spørsmålet, om pasienten har fattet en informert og kompetent beslutning, vil i praksis vurderes på samme måte som ved innhenting av et informert samtykke for medisinsk behandling. Det må avklares om pasienten har fått riktig og tilstrekkelig med informasjon til å fatte en god beslutning, jfr. pasient- og brukerrettighetsloven $\S 4-9$, 3. ledd, og det må avklares om pasienten er samtykkekompetent, jfr. § 4-3, 2. ledd (1).

I tråd med den kortfattede innledende sammenfatningen over ble det lagt til grunn at pasienten hadde truffet en informert og kompetent beslutning om å nekte helsehjelp. Pasienten hadde av flere helsepersonell både forut for innleggelsen og under undersøkelsen fătt tilfredsstillende informasjon om konsekvensene ved å nekte behandling. Det ble videre vurdert som sikkert at pasienten forsto hva dette innbefattet.

Det andre spørsmålet ble så om helsepersonellet like fullt var forpliktet til å yte helsehjelp uavhengig av om pasienten motsatte seg dette, eller om pasienten kunne nekte helsehjelp i en så alvorlig situasjon.

Spørsmålet er regulert i helsepersonelloven (2) § 7 og pasient- og brukerrettighetsloven $\S 4-9$ (1). Helsepersonelloven $\S 7,1$. ledd angir at helsepersonell «(...) skal straks gi den helsehjelp de evner når det må antas at hjelpen er påtrengende nødvendig. Med de begrensninger som følger av pasient- og brukerrettighetsloven $\S 4-9$, skal nødvendig helsehjelp gis selv om pasienten ikke er i stand til å samtykke, og selv om pasienten motsetter seg helsehjelpen.»

Spørsmålet var om $\S 7$ kom til anvendelse i dette tilfellet. Av Helsedirektoratets rundskriv om helsepersonelloven med kommentarer er det bemerket at kravet til «påtrengende nødvendig» hjelp omfatter «... situasjoner der det oppstår et akutt behov for undersøkelse og behandling, blant annet for å gjenopprette og/eller vedlikeholde vitale funksjoner, for å forhindre eller begrense alvorlig funksjonsnedsettelse som følge av skade og sykdom eller for å gi akutt smertelindring» (3). Kravet til «påtrengende nødvendig» var således åpenbart oppfylt i dette tilfellet.

Etter hovedregelen i helsepersonelloven $\S 7$ skulle det m.a.o. vært gitt helsehjelp selv om pasienten motsatte seg dette. Det fremgår imidlertid av $\S 7$ at denne bestemmelsen ikke kommer til anvendelse for de unntakstilfeller som følger av pasient- og brukerrettighetsloven $\S 4-9$, 1. ledd, der det bl.a. presiseres at pasienten «... har på grunn av 
alvorlig overbevisning rett (...) til å nekte å avbryte en pågående sultestreik»».

Formuleringen reiste således ytterligere to spørsmål, nemlig:

- forelå det en «alvorlig overbevisning»?

- hva ligger det $\mathrm{i}$ «rett til å nekte å avbryte»?

Kravet til «alvorlig overbevisning» er i liten grad omtalt i lovens forarbeider eller aktuelle rundskriv. I kommentarutgaven til loven (4) er det bemerket at «alvorlig overbevisning» ikke stiller krav til en bestemt begrunnelse, men at overbevisningen kan være «politisk, moralsk eller religiøst motivert». Det anføres imidlertid at overbevisningen må være av en «viss fasthet og varighet» og at den må basere seg på en «selvvalgt og rasjonell forestilling». I det aktuelle tilfellet fremsto det derfor rimelig å anvende unntaksbestemmelsen i pasient- og brukerrettighetsloven $\S 4-9$. Pasienten hadde over lengre tid vist at han ville holde fast ved sin oppfatning og aksjon, og begrunnelsen var rasjonelt forankret i en politisk protestaksjon.

Det påfølgende spørsmålet ble så hvordan man skulle tolke retten til «å nekte å avbryte» sultestreiken. Det ble her diskutert hvor langt man måtte la sultestreiken gå for at et inngrep ikke skulle innebære et avbrudd i en slik rettighet. Mer konkret ble det reist spørsmål ved om man kunne gi pasienten intravenøs ernæring etter at pasienten var blitt bevisstløs.

Bestemmelsens ordlyd kan gi grunnlag for tvil. Pasientens evne til å motsette seg behandling vil i praksis bortfalle ved bevisstløshet, og på det tidspunktet kan det reises tvil ved om man «avbryter» en streik når helsehjelp ytes på en bevisstløs pasient. Lovens forarbeider er imidlertid klar på at ethvert inngrep vil være rettsstridig: «Bestemmelsen innebærer at helsepersonell ikke har rett til å gripe inn med tvangsmessig behandling selv om pasienten vil kunne dø som følge av sin beslutning. Helsepersonell kan heller ikke gripe inn etter at pasienten har blitt bevisstløs» (5). Dette er også understøttet i Helsedirektoratets rundskriv til loven og i kommentarutgaven til loven $(6,7)$.

I dette tilfellet var det med andre ord klart at dersom det ikke lot seg gjøre å få samtykke til frivillig behandling av pasienten, ville det rettslig sett ikke være anledning til å påbegynne behandling $\mathrm{i}$ etterkant når pasienten eventuelt hadde tapt bevisstheten. Man var således henvist til å la pasienten dø om han ikke frivillig ville ta til seg ernæring eller motta helsehjelp.

\section{Etiske problemstillinger}

Parallelt med den juridiske diskusjonen ble det diskutert hvordan man skulle forholde seg til de etiske problemstillingene saken reiste. Det var særlig to hovedhensyn som ble stående opp mot hverandre, nemlig hensynet til pasientens autonomi mot hensynet til den profesjonsetiske plikten å verne om pasientens liv og helse. Ikke overraskende var det blant involvert helsepersonell ulike syn på hva som i hovedsak skulle vektlegges i det aktuelle tilfellet.

Hensynet til pasientens autonomi og retten til selvbestemmelse har i stadig større grad fått innpass i helseetikken og helseretten, og da ofte på bekostning av den paternalistiske tilnærmingen der beslutningen om helsehjelp til stor grad tidligere har ligget hos helseper-

\section{«Kravet til samtykke er nå den klare hoved- regelen for all helse- hjelp som gis»}

sonellet. Hovedregelen om krav til informert samtykke til helsehjelp etter pasient- og brukerrettighetsloven $\S 4-1$ er nettopp et utslag av hensynet til pasientens autonomi, og kravet til samtykke er nå den klare hovedregelen for all helsehjelp som gis.

De ovennevnte begrensningene som fremgår av helsepersonelloven $\S 7$, der helsepersonell uavhengig av pasientens samtykke skal gi helsehjelp der det må antas at hjelpen er påtrengende nødvendig, utgjør imidlertid et eksempel på unntaket fra autonomiens klare hovedregel. Det er således lagt til grunn at ved påtrengende nødvendige situasjoner skal helsepersonellets plikt til å verne om liv og helse som utgangspunkt gå foran pasientautonomien.

I denne hjelpeplikten er det imidlertid igjen gjort unntak for tre ulike situasjoner der lovgiver har ment at pasientens autonomi bør ha forrang til tross for det påtrengende behovet. Disse unntakene er listet i pasient- og brukerrettighetsloven $\S 4-9$, og utgjør retten til å nekte å avbryte sultestreik (som drøftet over), retten til å nekte å motta blodprodukter samt retten til å nekte livsforlengende behandling.

Den avveiningen lovgiver har gjort mellom den profesjonsetiske hjelpeplikten og pasientens selvbestemmelsesrett gjennom bestemmelsene i helsepersonelloven $\S 7$ og pasient- og brukerrettighetsloven $\S 4-9$ fremstår ikke uten videre klar. For mange fremstår det rimelig at selvbestemmelsesretten avgrenses mot de tilfeller der tap av liv og helse blir for stort. Hjelpeplikten, i strid med pasientens selvbestemmelsesrett i påtrengende tilfeller, kan således fremstå rimelig begrunnet for mange.

Det aktuelle regelverket synes imidlertid ikke å reflektere noen konsekvent avveining mellom de ovennevnte hovedhensyn i så måte. Særlig synes det noe tilfeldig at de to unntakene for sultestreik og reservasjon mot blodprodukter er uforbeholdent inntatt uten avveining for hvor stort tap dette vil utgjøre for liv og helse. Det synes videre heller ikke som om regelverket konsekvent har tatt hensyn til at det er graden av den særskilte overbevisningen som skal avgjøre retten til å reservere seg mot helsehjelp. Dersom eksempelvis vår pasient i stedet hadde uttrykt sin politiske demonstrasjon ved å tenne på seg selv, ville forholdet ikke vært unntatt fra hjelpeplikten i helsepersonelloven $\S 7$, da dette ikke er listet blant unntakene i pasient- og brukerrettighetsloven $\S 4-9$. Dette til tross for at overbevisningsgrunnlaget er det samme. Det synes her lite forståelig at valget av dødsmåte skal være utslagsgivende for om hjelpeplikten eller pasientautonomien skal ha forrang.

\section{Problematisk regelverk}

Det kan nevnes at tilsvarende juridiske og etiske problemstillinger rundt reservasjonsretten mot blodprodukter nylig ble diskutert av Bahus \& Førde i en kronikk i Tidsskriftet (8), og for dette unntaket reises tilsvarende innvendinger med noen ytterligere problemstillinger knyttet til spørsmålet om hvorvidt det er rimelig at pasienten kan kreve helsehjelp med samtidig rett til å legge premissene for hvordan helsehjelpen skal ytes.

Pedersen \& Nordtvedt har også reist kritiske innvendinger til utformingen av reglene i helsepersonelloven $\S 7$ og pasient- og brukerrettighetsloven§ 4-9 (9). De påpeker at reglene inneholder «uklare, inkonsistente og urimelige føringer, som gir unødvendig store utfordringer for helsepersonell som skal omsette juridiske føringer i praksis».

Vårt tilfelle synes å understøtte de oppfatninger og innvendinger som tidligere har vært reist mot disse bestemmelsene. Reglene rundt pasienters rett til å nekte helsehjelp versus helsepersonellets hjelpeplikt synes ikke å representere noen konsekvent avveining av de viktige hensynene som må tas i slike situasjoner. Bestemmelsene er for øvrig ikke enkle å tolke for helsepersonell, som ofte må forholde seg til dette i pressede situasjoner. Uten at vi med dette ønsker å ta et standpunkt $i$ spørsmålet om hvor grensene bør gå, synes vi det er rimelig at disse problemstillingene belyses. Regler av så stor viktighet bør i større grad være gjenstand for debatt og krav til utforming fra vår egen profesjon enn det de kan synes å ha vært til nå. 
Pasienten har gitt samtykke til at artikkelen blir publisert.

\section{Jørgen Dahlberg (f. 1974)}

er advokat, lege i spesialisering ved Anestesiklinikken på Akershus universitetssykehus og har en stipendiatstilling ved Institutt for klinisk medisin, Universitetet i Oslo, der han forsker på spørsmål knyttet til informert samtykke og samtykkekompetanse i somatikken. Forfatter har fylt ut ICMJE-skjemaet og oppgir ingen interessekonflikter.

\section{Vegard Dahl (f. 1954)}

er spesialist i anestesiologi, avdelingssjef ved Anestesiklinikken, Akershus universitetssykehus og professor II i anestesiologi ved Institutt for klinisk medisin, Universitetet i Oslo, Campus Ahus. Forfatter har fylt ut ICMJE-skjemaet og oppgir ingen interessekonflikter.

\section{Litteratur}

1. LOV-1999-07-02-63. Lov om pasient- og brukerrettigheter (pasient- og brukerrettighetsloven). http://lovdata.no/dokument/NL/Lov/1999-07-02-63 (7.7.2014).

2. LOV-1999-07-02-64. Lov om helsepersonell m.v. (helsepersonelloven). http://lovdata.no/dokument/ NL/lov/1999-07-02-64 (7.7.2014).

3. Helsedirektoratet. Helsepersonelloven med kommentarer. Rundskriv IS-8/2012: 24-6.
4. Syse A. Pasientrettighetsloven med kommentarer Oslo: Gyldendal Akademiske, 2009: 339-40.

5. Ot.prp. nr. $12(1998-99)$. Lov om pasientrettigheter (pasientrettighetsloven). Kap. 12 Merknader til utkastet til lov om pasientrettigheter, til § 4-9. www.regjeringen.no/nb/dep/hod/dok/regpubl/ otprp/19981999/otprp-nr-12-1998-99-/ 12.html? id=159427 (7.7.2014).

6. Helsedirektoratet. Lov om pasientrettigheter Rundskriv IS-12/2004: 36.

7. Syse A. Pasientrettighetsloven med kommentarer. Oslo: Gyldendal Akademiske, 2009: 339-40.

8. Bahus M, Førde R. Når pasienten nekter blodoverføring. Tidsskr Nor Legeforen 2014; 134: 850 - 1.

9. Pedersen R, Nordtvedt P. Når kan pasienten nekte helsehjelp? Kritisk Juss 2006; 32: 229 - 53.

Mottatt 31.7. 2014, første revisjon innsendt 13.10. 2014, godkjent 28.10. 2014. Redaktør: Are Brean. 